\title{
Tenure, Turnover, And Earnings Profiles In Germany And The United States
}

Kenneth A. Couch (Email: kenneth.couch@uconn.edu), University of Connecticut

\begin{abstract}
Employment tenure, job turnover and returns to general and specific skills are examined for male workers in Germany and the United States using data from the German Socio-Economic Panel and the Panel Study of Income Dynamics. Employment in Germany is characterized by longer duration and less frequent turnover than in the United States. Returns to experience and tenure are lower in Germany than in the U.S.; however, peak earnings occur later. This delayed peak in the employment-earnings profile provides an incentive for German workers to remain longer with their employers and change jobs less frequently.
\end{abstract}

\subsection{Introduction}

D eterminants of workers' wages are fundamental to understanding labor market activity. An extensive theoretical literature provides competing explanations for observed patterns in wage rates, and an active empirical literature has confronted those theories with evidence. The vast majority of this research has focused on individual labor markets, and in particular, on the United States. While much has been learned, a fairly open question is how well standard theories explain differences in wage setting processes across countries. The research contained in this paper explores that topic by providing an initial examination of the determinants of pay in Germany relative to the United States. ${ }^{1}$

A common empirical pattern reported from the earliest research is an upward sloping tenure-earnings profile along with an inverse relationship between turnover and tenure (Mincer 1962). Three major theories provide explanations for these basic empirical observations; human capital, job-matching, and efficiency wage.

According to human capital theory, workers are paid according to the value marginal product of general and specific labor market skills (Becker 1962 and Mincer 1962). General skills are transportable to other employers and specific skills are not. Since general skills are portable, firms should not pay for their financing. Jobs providing general skills should have lower starting wages and a positively sloped experience-earnings profile. Specific skills are not transportable and might be financed by the firm or the individual. If financed by the firm, one would expect the employer to pay enough to the employee to discourage movement to their next best job opportunity so that the investment can be recouped. If financed by the employee, a job would be characterized by lower starting pay and a relatively more steeply sloped wage-earnings profile than in the case of firm financing or absence of training. Intermediate cases of shared investment are also possible (Hashimoto 1981; Hashimoto 2001; and Leuven and Oosterbeek 2001). Regardless of the source of financing, the rising earnings profile induces a negative correlation between tenure and either quit rates or turnover (Parsons 1972).

In matching models, individuals receive job offers during their lifetimes, successively accepting offers which provide a better fit between them and attributes of the firm (Burdett 1978; Jovanovic 1979; and Flinn 1986). Thus, these models generate positively sloped tenure-earnings profiles which are independent of worker skill. Turnover is negatively related to tenure due to match quality.

Readers with comments or questions are encouraged to contact the author via email. 
In efficiency wage models, worker productivity is influenced by pay (Lazear 1981). Young workers are paid less and older workers are paid more than their value marginal product. This scheme induces young workers to put forth effort in order to stay with a firm until they can be overpaid as an older worker. For older workers, the incentive is to work hard in order to continue being paid more than their value. In the model, wages grow with tenure even in the absence of firm training. The incentive pay scheme also induces a negative correlation between tenure and turnover.

A substantial empirical literature has sought to distinguish which factors from among these theories best explain patterns observed in returns to years of employment. Human capital theory indicates that training on the job, whether worker or firm financed, and whether general or specific, should result in upward sloping wage profiles. To estimate the relative contributions of general and specific skills in the theory, empirical researchers have typically focused on years of total work experience as a proxy for time spent gaining general labor market skills. Similarly, the duration of employment with a single employer, tenure, is used as a proxy for time potentially spent acquiring specific labor market skills. From the earliest work (Mincer 1962), the basic empirical pattern of positively sloped experience and tenure profiles has been universally reported.

The empirical observation that years of experience and tenure are each positively related to earnings is consistent with human capital theory but does not rule out other explanations. Job-matching theories also predict upward sloping tenure-wage profiles, and a body of empirical work has examined the extent to which matching is responsible for this observation.

Some of that research takes an econometric approach to isolating the effect of job matching relative to tenure (Flinn 1986; Altonji and Shakotko 1987; and Topel 1991). Based on those articles, one would reasonably conclude that job matching plays some role in generating observed returns to tenure although estimates of the exact contribution vary.

In order to move away from econometric restrictions in attempts to identify the effect of matching on returns to tenure, a more recent literature has exploited longitudinal data from job displacements (Kletzer 1989; Ruhm 1991; and Neal 1995). The argument behind these papers is that permanent job loss is an exogenous event uncontrolled by individual workers. Comparing earnings before and after the event of an exogenously imposed job loss should reveal the extent to which returns to tenure are associated with factors related to that specific job match as opposed to skills which have become imbedded in the productive capital of the individual worker and are now transportable across employers.

In each of these papers (Kletzer 1989; Ruhm 1991; and Neal 1995), years of job tenure prior to displacement are found to be positively related to post-displacement earnings. Kletzer (p. 539) reports that the returns to predisplacement tenure in post-displacement employment vary across blue and white collar workers. She concludes that job match quality plays a larger role for returns to tenure for blue than white collar workers. Similarly, Neal shows that those re-employed in the same industry following displacement are rewarded for tenure at virtually the same rate as before it occurred. Those who change industries lose most of the returns to prior seniority. Thus, the match between the worker and employer is important. An additional observation is that the ability of workers to preserve returns to tenure following job switches within an industry suggests that workers in the U.S. finance much of their own skill acquisition.

Efficiency wage theories also generate upwardly sloping tenure-earnings profiles. One testable implication of the theory is that tenure-earnings profiles should be more flatly sloped in segments of the labor market where agency problems are not as large (Lazear and Moore 1986). Also, since earnings will increase with tenure in the absence of productivity gains, returns to tenure will occur in firms with no training. Levine (1993) finds that firms that provided more training did not exhibit larger returns to tenure. Other researchers have investigated whether pay is linked with firm measures of worker productivity such as job evaluations and have found that the link is weak (Medoff and Abraham 1980 and 1981). Thus, there is also empirical support for the view that firms use considerations beyond productivity in their wage setting process. 
In summary, these theoretical and empirical literatures have advanced together in attempting to explain which factors in the labor market lead to positively sloped tenure-earnings profiles and the corresponding negative correlation with job turnover. All of the theories are attempting to explain this overarching empirical pattern. At this point, most would agree that the market rewards general and specific skills and that returns to tenure additionally reflect both the quality of the job match as well as attempts of firms to raise productivity through the structure of compensation.

While our understanding of factors which contribute to observed wage profiles and the inverse relationship between employment tenure and turnover has progressed, little attention has been paid to whether our basic understanding of how rewards in the labor market are related to tenure and turnover holds across societies. The only comparative investigations of this type were made for Japan relative to the United States (Hashimoto and Raisian 1985 and Levine 1993).

The work of Hashimoto and Raisian (1985) was motivated by the superior economic performance of Japan relative to the United States in the 1970s and 1980s and the observation that the Japanese labor market appeared to be characterized by longer attachments between firms and employees. Using nationally representative data, they found that returns to additional years of employment are higher and peak later in Japan than in the U.S. From this, they concluded that Japanese workers had a stronger incentive to remain with one employer, and this was reflected in lower rates of turnover and higher years of tenure in the Japanese labor market.

Levine (1993) used samples of matched firms and workers in Japan and the United States to critically examine whether human capital theory was consistent with the positively sloped employment-earnings profiles in the two countries. Focusing primarily on whether firms that provide more training have steeper tenure-wage profiles and whether firms with higher returns to tenure have lower turnover, Levine presented evidence against both of these hypotheses. He concludes that human capital theory is not consistent with the evidence presented and suggests that efficiency wage theory provides a better explanation of wage setting in the two countries.

While the existing literature has largely focused on individual countries in isolation, the research strategy chosen here is to make a comparison of two countries. The aim of the research is to provide an examination of whether returns to skills are broadly predictive of differential patterns of employment tenure and labor turnover in Germany and the United States. To begin, basic information regarding the duration of tenure and job turnover is provided for each country.

\subsection{Employment Tenure and Job Turnover in the U.S. and Germany}

Incentives for workers to stay with an employer are reflected in years of continuous employment. Table 1 contains information regarding years of employment tenure for various age groupings in Germany and the United States. The figures reported in the table are calculated using data from the Panel Study of Income Dynamics (PSID) for the United States and from the German Socio-Economic Panel (GSOEP) for Germany for the years from 1984 through 1992. The figures in this table and all others in the paper are weighted to account for the longitudinal nature of the data. Male workers ages 18 to 60 are included in the sample. Additional selection criteria are that the worker must be employed 1000 hours in the year and must report annual earnings of 1000 Deutsche Marks or the U.S. equivalent. Self-employed and government workers are excluded. This sample is used in all of the analyses presented in the paper. There are 10,440 observations from the PSID and 9,450 from the GSOEP.

Among male workers ages 18 to 60, median employment tenure in Germany is seven years versus four for the United States. Tenure is low in both countries in the early stages of labor market activity as would be expected. By mid-life, German workers remain longer with their employers. Among male workers ages 35-44, median tenure in Germany is ten years as opposed to seven in the U.S. In later years of working activity in the United States, median tenure declines. As a result, in the oldest age range examined, median tenure is 16 years in Germany versus 8 in the U.S. The attachment of workers to employers is more durable in Germany than in the United States, particularly as workers become older. 
Table 1: Distribution of Male Population by Age and Tenure 1984-1992

\begin{tabular}{|l|c|c|c|c|c|c|}
\hline & \multicolumn{3}{|c|}{ United States } & \multicolumn{3}{c|}{ Germany } \\
\hline Age & $\begin{array}{c}\text { Median } \\
\text { Tenure }\end{array}$ & $\begin{array}{c}\text { Less Than } \\
\text { 10 Years }\end{array}$ & $\begin{array}{c}\text { More Than } \\
\text { 15 Years }\end{array}$ & $\begin{array}{c}\text { Median } \\
\text { Tenure }\end{array}$ & $\begin{array}{c}\text { Less Than } \\
\text { 10 Years }\end{array}$ & $\begin{array}{c}\text { More Than } \\
\text { 15 Years }\end{array}$ \\
\hline $\mathbf{1 8 - 1 9}$ & 1.0 & 100.0 & 0.0 & 0.0 & 100.0 & 0.0 \\
\hline $\mathbf{2 0 - 2 4}$ & 2.0 & 100.0 & 0.0 & 1.0 & 100.0 & 0.0 \\
\hline $\mathbf{2 5 - 3 4}$ & 3.0 & 86.0 & 3.0 & 4.0 & 83.0 & 3.0 \\
\hline $\mathbf{3 5 - 4 4}$ & 7.0 & 59.0 & 25.0 & 10.0 & 48.0 & 29.0 \\
\hline $\mathbf{4 5 - 4 9}$ & 11.0 & 48.0 & 41.0 & 14.0 & 33.0 & 49.0 \\
\hline $\mathbf{5 0 - 6 0}$ & 8.0 & 53.0 & 39.0 & 16.0 & 35.0 & 53.0 \\
\hline All Ages & 4.0 & 70.0 & 19.0 & 7.0 & 58.0 & 27.0 \\
\hline
\end{tabular}

Source: The numbers reported in the table were calculated by the author using data from the Panel Study of Income Dynamics for the United States and the German Socio-Economic Panel for Germany. Data from both surveys were drawn from the panel years from 1984 through 1992 and are weighted to account for their longitudinal nature. Other than the median tenure figures reported, the other table entries are percentages.

A brief examination of the tails of the distribution of years of tenure supports this conclusion. Among all male workers in the United States, 70 percent have less than 10 years of tenure and 19 percent have more than 15 years. In Germany, 58 percent have less than 10 years of tenure while 27 percent have more than 15 years. In Germany relative to the United States, fewer workers have short durations with their employer and more have longer durations. This pattern is driven by older workers in Germany being characterized by having longer durations of employment than are observed in the United States.

The conclusion that the labor market in the United States is characterized by a shorter duration of tenure is important in what follows. It would be helpful to know if the numbers calculated here agree with other sources of information. While a comparative source of data is not available for Germany, the numbers shown in table 1 for the United States accord well with official statistics. For example, the Statistical Abstract of the United States reports that in 1998, median years of tenure for workers ages 16 and over is 3.7 years and is 4.0 years for workers ages 20 and over. Here, it is calculated that years of tenure for a sample ages 18 to 60 is 4.0 years. Perhaps of greater concern for the United States data is the rising pattern for years of tenure that declines at later ages. In the Statistical Abstract, the same pattern is observed. Although the numbers calculated here are from panel data and the official statistics are based on cross-sectional data with a larger sample, the figures are nonetheless close in their levels and exhibit similar patterns in the movement of years of tenure with age. ${ }^{2}$

All of the major theories which generate positively sloped tenure-earnings profiles predict not only increasing tenure with age but also decreasing turnover. Table 2 contains turnover information for the United States and Germany calculated as the average number of new job starts for the same age groups considered in table 1. In both countries, turnover declines rapidly as workers enter their twenties. In Germany, turnover rates remain low thereafter for the remainder of the age ranges considered in the table. In the U.S., turnover rates decline but then rise again. This overall pattern is similar to the one seen in tenure. Years of tenure expanded monotonically conditional on age for Germany while turnover declines. In the U.S., years of tenure initially increased but declined for older workers -turnover declines before expanding.

Comparing the two countries, in every age interval after age 20, German workers start fewer new jobs than American workers. From the mid-30s onward, American workers appear to have at least double the chance of a typical German of beginning new employment. For example, American workers in the age bracket from 35-44 have a 33 percent chance of starting new employment versus a 13 percent chance in Germany. From ages 50-60, the chance of a German worker beginning new employment is 22 percent versus 42 percent in the U.S. Thus, the patterns in turnover for Germany and the United States are similar to those seen for years of tenure. German workers, particularly in later years of their working lives, experience less turnover and thus accumulate more employment tenure than American workers. 
Table 2: Number of Different Jobs Per Male Worker: Germany and the United States 1984-1992

\begin{tabular}{|l|c|c|c|c|c|}
\hline & & \multicolumn{4}{|c|}{ New Jobs Started Per Year } \\
\hline & & \multicolumn{3}{|c|}{ Per Person } & \multicolumn{2}{c|}{ Over the Age Interval } \\
\hline & & Germany & U.S. & Germany & U.S. \\
\hline Age & $18-19$ & .29 & .28 & .88 & .84 \\
\hline & $20-24$ & .10 & .12 & .50 & .61 \\
\hline & $25-34$ & .02 & .04 & .24 & .42 \\
\hline & $35-44$ & .01 & .03 & .13 & .33 \\
\hline & $45-49$ & .02 & .06 & .13 & .31 \\
\hline & $50-60$ & .02 & .04 & .22 & .42 \\
\hline
\end{tabular}

Source: These figures are based on calculations from the PSID and GSOEP of new job starts over the relevant age intervals. In both countries, new starts are counted as jobs with less than one year of tenure. Data are used from the panel years from 1984 through 1992 in both countries. For more information on the sample, see the description in the text.

\subsection{Returns to Experience and Tenure in Germany and the United States}

The rate of increase in wages directly influences observed years of tenure and rates of employment turnover. To calculate returns to employment for Germany and the United States, panel regressions of log wages on standard explanatory variables are estimated using the samples of male workers from the PSID and GSOEP which have been previously described.

For the variables used to decompose the employment experience of a typical worker into proxies for their general and specific skills, conventions in the literature regarding their measurement are followed. In both data sets, retrospective information on years of full-time employment experience is used to calculate years of total labor market experience. This variable is considered a proxy for general labor market skills. Also, information regarding years of employment with a specific employer is used to calculate years of tenure for the workers in each country. This variable is considered a proxy for specific skills. Other regressors included in the analysis are marital status and years of schooling. The dependent variable is the natural log of average hourly wages calculated as annual labor earnings divided by annual work hours. The wages are measured as real 1984 figures. Means and standard deviations of the pooled sample of observations from each country are reported in table 3 .

Table 3: Regressions of Male Wages for Germany and the United States: 1984-1992

\begin{tabular}{|c|c|c|c|c|}
\hline & \multicolumn{2}{|c|}{ Means and Standard Deviations } & \multicolumn{2}{|c|}{$\begin{array}{r}\text { Regressions } \\
\end{array}$} \\
\hline & United States & Germany & United States & Germany \\
\hline \multicolumn{5}{|l|}{ Regressors: } \\
\hline Experience & $11.44(8.10)$ & $19.21(11.42)$ & $.069(.005)$ & $.029(.002)$ \\
\hline Experience $^{2}$ & $1.96(2.59)$ & $4.99(4.67)$ & $-.601(.057)$ & $-.205(.022)$ \\
\hline Experience $^{3}$ & $4.26(7.86)$ & $14.73(17.88)$ & $.220(.026)$ & $.059(.008)$ \\
\hline Experience $^{4}$ & $10.57(24.11)$ & $46.74(68.53)$ & $-.028(.004)$ & $-.006(.001)$ \\
\hline Tenure & $8.59(8.12)$ & $11.04(8.73)$ & $.038(.004)$ & $.013(.002)$ \\
\hline Tenure $^{2}$ & $1.40(2.44)$ & $1.98(2.66)$ & $-.216(.044)$ & $-.105(.023)$ \\
\hline Tenure $^{3}$ & $3.08(7.68)$ & $4.38(8.39)$ & $.058(.018)$ & $.039(.010)$ \\
\hline Tenure $^{4}$ & $7.93(25.72)$ & $11.02(27.9)$ & $-.006(.003)$ & $-.005(.001)$ \\
\hline Years of School & $12.76(2.44)$ & $11.46(2.52)$ & $.048(.001)$ & $.018(.001)$ \\
\hline Marital Status & $.71(.45)$ & $.75(.43)$ & $.046(.006)$ & $.030(.004)$ \\
\hline Log Wages & $.87(.31)$ & & ----------------- & ----------------- \\
\hline R-Squared & |--------------- & |--------------- & .34 & .26 \\
\hline $\mathbf{N}$ & 10,110 & 8,281 & 10,110 & 8,281 \\
\hline
\end{tabular}

Source: The estimates presented in the table are based on calculations by the author using data drawn from the 1984 through 1992 years of the PSID and GSOEP. A full description of the sample is contained in the text. The estimates are weighted to reflect the longitudinal 
nature of the data. Entries in the columns for mean and standard deviation take the form: mean(standard deviation). Entries in the columns for the regressions take the form: parameter(standard error).

The equation estimated can be written as:

$Y_{i t}=\alpha+\beta_{1} j_{i t}+\beta_{2} j_{i t}^{2}+\beta_{3} n_{i t}+\beta_{4} n_{i t}^{2}+\varepsilon_{i t}$

$\mathrm{Y}$ refers to the $\log$ of average hourly wages. The subscript i refers to individuals, and $t$ refers to the time period. $\mathrm{J}$ represents years of full-time job experience for worker $\mathrm{i}$ at time $\mathrm{t}$. $\mathrm{N}$ represents years of tenure with an employer for worker i at time t. $\varepsilon$ is measurement error.

In addition to the means and standard deviations of the variables, table 3 contains parameter estimates from the regressions for Germany and the United States. Based on those estimates, in the U.S., the estimated return to a year of experience is 4.8 percent and for an additional year of employment tenure is 5.2 percent. For Germany, the returns to both experience and tenure are much lower than in the United States. Returns to years of experience are 1.9 percent and 1.5 percent for a year of tenure. The returns to both experience and tenure in Germany and the United States have the expected shape in that they increase at a decreasing rate. This can be seen by the negative signs of the parameter estimates associated with squared terms for tenure and experience in each country. All of the relevant parameter estimates are statistically significant at conventional levels.

The result that returns to experience and tenure in Germany are low relative to the United States is striking. Whether these returns are consistent with patterns of the duration of tenure and labor turnover, however, depends on how many years of employment pass before the returns peak as opposed to the rate of increase in an individual year. Table 4 contains calculations in each country of the total returns to additional years of work for someone who is continuously employed along with the peak years of the wage profiles. The total returns are decomposed for the two countries into the contributions from experience and tenure. ${ }^{3}$ For each of the measures considered, returns to experience, returns to tenure, and the total, the wage profile peaks much later in Germany than in the United States. For example, returns to tenure in Germany peak after 37 years of employment versus 24 in the U.S. Returns to years of employment peak after 20 years in the U.S. and after 28 in Germany. These comparatively later peaks in employment-earnings profiles provide an incentive for German workers to remain with their employers relatively longer than would be expected in the U.S.

Table 4: Percent Growth in Earnings Due to Experience and Tenure for Continuous Employment in Germany and the United States

\begin{tabular}{|c|c|c|c|c|c|c|}
\hline & \multicolumn{3}{|c|}{ United States } & \multicolumn{3}{|l|}{ Germany } \\
\hline & Experience & Tenure & Total & Experience & Tenure & Total \\
\hline \multicolumn{7}{|l|}{ Tenure } \\
\hline 5 years & 14 & 21.5 & 35.5 & 8.3 & 6.9 & 15.2 \\
\hline 10 years & 23 & 38 & 61 & 14.6 & 12.8 & 27.4 \\
\hline 15 years & 27 & 49.5 & 76.5 & 18.9 & 17.7 & 36.6 \\
\hline 20 years & 26 & 56 & 82 & 21.2 & 21.6 & 42.8 \\
\hline 25 years & 20 & 57.5 & 77.5 & 21.5 & 24.5 & 46 \\
\hline 30 years & 9 & 54 & 63 & 19.8 & 26.4 & 46.2 \\
\hline Peak & 17 & 24 & 20 & 23 & 37 & 28 \\
\hline
\end{tabular}

Source: These figures are calculated using the regression parameters presented in table 3 . Returns to experience and tenure are calculated respectively as $\partial y / \partial j$ and $\partial y / \partial n$. The total return is calculated as the sum of these two parts. 


\subsection{Conclusion}

The patterns of returns to experience and tenure observed in Germany and the United States are broadly consistent with each of the major theories developed to explain the relationship of returns to tenure and turnover. In both countries, returns to experience and tenure are positive and increase at a decreasing rate. In terms of both experience and tenure, wage profiles in Germany peak later than in the U.S. As a result, the employment-wage profile also peaks later in Germany.

Comparatively, one would expect that a country with a later peak in the employment-wage profile would also have longer employment durations and lower rates of labor turnover, particularly as workers move beyond their early years of job searching. Those patterns are observed here with respect to Germany and the United States. Germany has longer median employment tenure and lower labor turnover than in the United States.

While these broad patterns are consistent with any of the major theories used to explain the relationship between returns to skill and employment tenure, an interesting and unexplained result is the relatively lower returns to both experience and tenure in the German economy. Institutionally, Germany operates in a more collective manner at the industry level to provide training to workers. This is seen in their dual system of education where high school students simultaneously undertake trade apprenticeships and supportive industry specific courses. The training of these workers is financed in part by the relevant industry group. The lower returns to experience, tenure, and education in Germany are consistent with industry financing of a large component of the training. Wages would be predicted to increase more slowly because the firms in the industry are attempting to recoup their investment in the worker. While this is conjecture, it nonetheless casts an interesting perspective on the belief that wage dispersion is lower in Germany due to social norms. In part, the relatively small dispersion of wages (and earnings) in Germany may be due to the nature of shared investments in worker skills. Investigating this conjecture remains for future research.

\section{References}

1. Altonji, Joseph G. and Shakotko, Robert A. "Do Wages Rise with Job Seniority?" Review of Economic Studies, 1987, 3(179), pp. 437-459.

2. Becker, Gary S. "Investment in Human Capital: A Theoretical Analysis." Journal of Political Economy, Supplement October 1962, 70(5), pp. 9-49.

3. Burdett, Kenneth. "A Theory of Employee Job Search and Quit Rates." American Economic Review, March 1978, 68(1), pp. 212-220.

4. Flinn, Christopher J. "Wages and Mobility of Young Workers." Journal of Political Economy, June 1986, 94(3), pp. S88-s110.

5. Hashimoto, Masanori. "Firm Specific Human Capital as a Shared Investment." American Economic Review, June 1981, 71(3), pp. 475-482.

6. Hashimoto, Masanori. "Firm-Specific Human Capital as a Shared Investment: Reply." American Economic Review, March 2001, 91(1), pp. 348-349.

7. Hashimoto, Masanori and Raisian, John. "Employment Tenure and Earnings Profiles in Japan and the United States.” American Economic Review, September 1985, 75(4), pp. 721-735.

8. Jovanovic, Boyan. "Job Matching and the Theory of Turnover." Journal of Political Economy, October 1979, 87(5), pp. 972-990.

9. Kletzer, Lori G. "Returns to Seniority after Permanent Job Loss." American Economic Review, June 1989, 79(3), pp. 536-543.

10. Lazear, Edward P. “Agency, Earnings Profiles, Productivity, and Hours Restrictions.” American Economic Review, September 1981, 71(4), pp. 606-620.

11. Lazear, Edward P. and Moore, Robert L. "Incentives, Productivity, and Labor Contracts." in George A. Akerloff and Janet L. Yellen, eds., Efficiency Wage Models of the Labor Market. Cambridge University Press, 1986, pp. 135-156. 
12. Levine, David I. "Worth Waiting For? Delayed Compensation, Training, and Turnover in the United States and Japan." Journal of Labor Economics, October 1993, 11(4), pp. 724-752.

13. Leuven, Edwin and Oosterbeek, Hessel. "Firm-Specific Human Capital as a Shared Investment: Comment." American Economic Review, March 2001, 91(1), pp. 342-347.

14. Medoff, James L. and Abraham, Katherine G. "Experience, Performance, and Earnings," Quarterly Journal of Economics, December 1980, 95(4), pp. 703-736.

15. Medoff, James L. and Abraham, Katherine G. "Are Those Paid More Really More Productive: The Case of Experience," Journal of Human Resources, Spring 1981, 16(2), pp. 188-216.

16. Mincer, Jacob. "On-the-Job Training: Costs, Returns, and Some Implications." Journal of Political Economy, Supplement October 1962, 70(5), pp. 50-79.

17. Neal, Derek. "Industry-Specific Human Capital: Evidence from Displaced Workers." Journal of Labor Economics, October 1995, 13(4), pp. 653-677.

18. Parsons, Donald O. "Specific Human Capital: An Application to Quit Rates and Layoff Rates." Journal of Political Economy, December 1972, 80, pp. 1120-1143.

19. Ruhm, Christopher J. "Do Earnings Increase With Job Seniority?" Review of Economics and Statistics, February 1990, 72(), pp. 143-147.

20. Topel, Robert. "Specific Capital, Mobility, and Wages: Wages Rise with Job Seniority." Journal of Political Economy, February 1991, 99(1), pp. 145-177.

\section{Endnotes}

1. The paper considers only workers from the former West Germany in order to avoid issues associated with German reunification. Samples used in the paper cover the period from 1984-1992. Reunification occurred in 1989.

2. A more detailed examination may be made by reference to the Statistical Abstract of the United States: 1999 (table 670).

3. The returns to experience and tenure are calculated respectively as $\partial y / \partial j$ and $\partial y / \partial n$. The total is calculated as the sum of the individual parts. 